\title{
Relationships of Syrmaticus and Phasianus by Cyt-b Gene Array Comparison
}

\author{
Isao MunechiKa ${ }^{1}$, Kohei Nozawa ${ }^{2}$ and Hitoshi Suzuki ${ }^{3}$ \\ 1 Chiba Zoological Park, 280 Minamoto-cho, Wakaba-ku, Chiba 264-0037, \\ Japan \\ 2 TAKARA Bioproducts Center, 3-4-1 Seta, Otsu 520-2134, Japan \\ 3 Division of Bioscience, Graduate School of Enviromental Earth Science, \\ Hokkaido University, Kitaku, Sapporo 060-0810, Japan
}

\begin{abstract}
The relationships of Syrmaticus to Phasianus remain uncertain and opinions differ whether they are separate genera or congeneric. We examined the relationships of Syrmaticus to Phasianus, Lophura, and Catreus by means of $C y t-b$ gene array comparisons. As a result, we found that each of the following groups forms a cluster, (1) Syrmaticus soemmerringii, (2) Syrmaticus reevesii, (3) Syrmaticus ellioti, S. humiae, S. mikado and (4) Lophura erythrophthalma, Catreus wallichii and Phasianus versicolor. There was $10.81 \%$ difference between cluster(3), Elliot's, Hume's and Mikado Pheasant, and cluster(4), Crestless Fireback, Cheer and Green Pheasant (Phasiunus). The Cheer Pheasant, the taxonomic position of which has been debated, was included in the Green Pheasant cluster in our experimental data and hence considered to be more closely related to Phasianus than to Syrmaticus.
\end{abstract}

Key Words: Classification, Cyt-b gene, Phasianus, Syrmaticus

There are various opinions regarding the classification of the Copper Pheasant. Delacour (1977) and Johnsgard (1988) claim that the Copper Pheasant is of the genus Syrmaticus and includes five species, namely, Reeve's Pheasant, Mrs. Hume's Pheasant, Elliot's Pheasant, Mikado Pheasant and Copper Pheasant. However, Peters (1934), while recognizing the genus Syrmaticus, divides it into four subgenera, which he refers to as Syrmaticus, Graphephasianus, Calophasis and Cyanophasis. Checklist of Japanese Birds (The Ornithological Society of Japan 1974) includes these in the genus Phasianus and does not recognize the genus Syrmaticus. As reasons for recognizing the genus Syrmaticus, Delacour (1977) points out the clear differences between the down of the chicks in the two genera and that the five species of the genus Syrmaticus form a natural group clearly distinct from the genus Phasianus. Johnsgard(1986) claims that the genera Phasianus and Syrmaticus are not greatly divergent in terms of evolutionary history.

Morioka(1988), in common with Delacour (1977) and Johnsgard (1988), also considers the genus Phasianus and the genus Syrmaticus to be relatively close within the sub-family Phasianinae. However, since the genus Syrmaticus is sufficiently distinct in form and physiology, it should be considered an independent genus.

In terms of form, though the significance is not clear, Reeve's Pheasant has the 
most narrow facial protrusion and the most highly developed tail feathers of all of the species in the genus Syrmaticus. In addition, it also has the most extensive white portion on the head, an important signal of the male, and, in these respects, the Reeve's Pheasant differs from the other four species of Long-tailed Pheasants (Syrmaticus).

It is well known that the fertility of the $\mathrm{F} 1$ generation due to crossbreeding is an important tool in understanding affinity relationships and a number of examples have been reported.

Although the Reeve's Pheasant will crossbreed with the Copper Pheasant , the F1 generation has low fertility (Delacour, 1977) and, when crossbred with the Ringnecked Pheasant, F1 females are usually sterile and males have a low level of fertility (Knoder, 1963). These examples indicate that these two groups are not closely related.

However, since the genus Syrmaticus remains in doubt not only in its relationships to the genus Phasianus but also in terms of its taxonomic positioning within the genus, we attempted to clarify the unknowns in terms of molecular biology from mitocondrial $c y t-b$ gene arrays.

\section{MATERIALS AND METHODS}

In this research, the Northern Copper Pheasant (Syrmaticus soemmerringii scintillans), Elliot's Pheasant (Syrmaticus ellioti), Hume's Pheasant (Syrmaticus humiae), Mikado Pheasant (Syrmaticus mikado), Reeve's Pheasant (Syrmaticus reevesii), Crestless Fireback Pheasant (Lophura erythrophthalma), Cheer Pheasant (Catreus wallichii) and Green Pheasant (Phasianus versicolor) were used and the Red Jungle Fowl Gallus gallus was used as the out group.

DNA samples were extracted from blood samples or from livers taken from dead specimens using the usual methods.

DNA amplification was carried out by the PCR method and the primers used were the AGCCCCATCCAACATCTCTGCTTGATGAAA and TGGGGCCAAAT ATCATTCTGAGGGGCCACC arrays of Irwin et al. (1991) shortened to 30bp with positioning at 14961-15327(refer to Desjardins \& Morais 1990). The composition of the PCR reactant was $10 \mu \mathrm{l}$ of buffer used for Taq DNA polymerase and Taq DNA polymerase $2 \mathrm{U}$ (TAKARA), 20 pmol of each primer, $200 \mu \mathrm{M}$ of each dNTPs and the total amount was adjusted to $100 \mu \mathrm{l}$ each with distilled water. DNA used as the template was diluted step by step with sterilized distilled water and used after confirming the optimal concentration.

A Perkin Elmer Cetus PJ-200 thermal cycler was used in the PCR and we repeated the cycle of $94^{\circ} \mathrm{C}$ for 1 minute, $58^{\circ} \mathrm{C}$ for 1 minute and $72^{\circ} \mathrm{C}$ for 2 minutes 35 times after preheating to $94^{\circ} \mathrm{C}$ for 1 minute. After the completion of the reaction, samples were extracted from each sample tube and the outcome of the PCR was confirmed by means of agarose cataphoresis.

Since large quantities of unreacted dNTPs and oligomerized primer were included in the PCR reactant, refinement was carried out using the agarose purification method prior to sequencing. We carried out the dye terminator cycle sequencing reaction with 3 pmol of sequencing primer and about $0.1 \mu \mathrm{g}$ of the refined PCR product as the template and determined the arrays using an auto-sequencer (ABI model 373A-36). Unreadable primers, misread bases and bases impossible to 
analyze were determined through comparisons to the complementary base pair. In regard to the decoded $267 \mathrm{bp}$, sequence divergence was computed using the computer program Phylip 3.4 and the phylogenetic tree was formulated through NJ using the computer program DNASIS. Though there are many opinions regarding scientific name, we followed Delacour (1977).

\section{RESULTS}

In order to confirm the taxonomic positioning of the genus Syrmaticus, we decoded $C y t-b$ gene 267bp arrays of species classified as belonging to the genera Lophura, Catreus and Phasianus and carried out comparisons. The results are as indicated in Tables 1, 2 and Fig. 1.

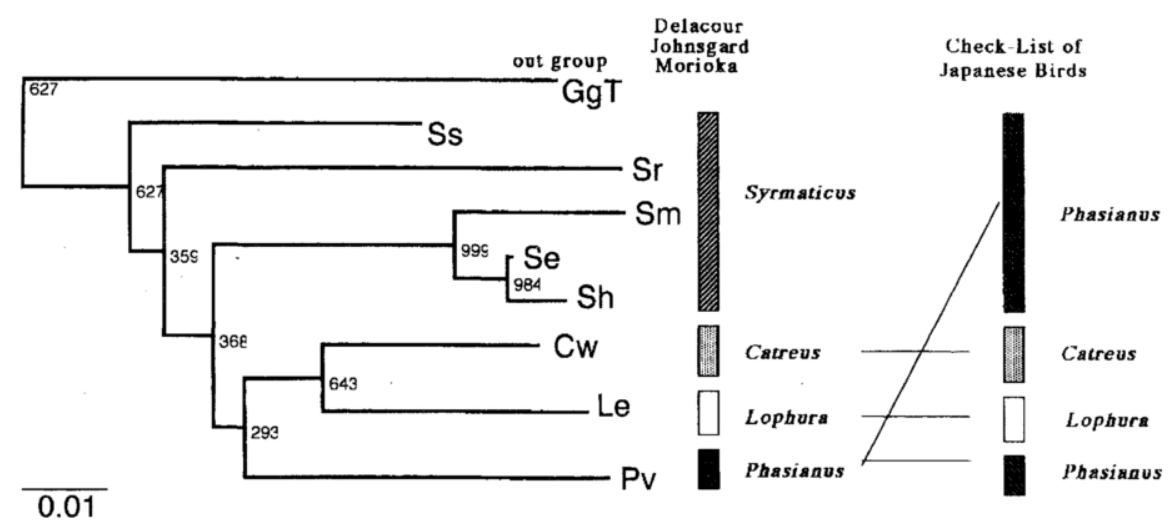

Fig. 1. A phylogentic tree for the $C y t-b$ gene constructed by the NJ method. Numbers above each node represent the bootstrap suppert (of 1000 replicates) for each branch.

Remarks: Ss: Syrmaticus soemmerringii scintillans, Sr: Syrmaticus reevesii, Sm: Syrmaticus mikado, Se: Syrmaticus ellioti, Sh: Syrmaticus humiae, Cw: Catreus wallichii, Le: Lophura erythophthalma, Pv: Phasianus versicolor, GgT: Gallus gallus (out group) numbered bootstrap

On the basis of the extent of sequence divergence (Table 2), we constructed the phylogentic tree for the $C y t-b$ gene of the Long-tailed Pheasant group and the group containing some true Pheasants by NJ method (Fig. 1).

The $C y t-b$ gene tree indicated that the Copper Pheasant (Syrmaticus soemmerringii scintillans) diverged the earliest from the others, Reeve's Pheasant then diverged, and the other 3 species of the Long-tailed Pheasant group and Green Pheasant group diverged, after the Green Pheasant group diverged from the Longtailed Pheasant group. Between the Green Pheasant (Phasianus) and the group containing some of the Long-tailed Pheasants (Elliot's, Hume and Mikado Pheasants) of the genus Syrmaticus, the rate of SD ranged from 7.87\% (Elliot's Pheasant) to $10.81 \%$ (Mikado Pheasant).

The time of divergence between clusters (3) and (4) is calculated to be $5.70 \mathrm{Myr}$. 

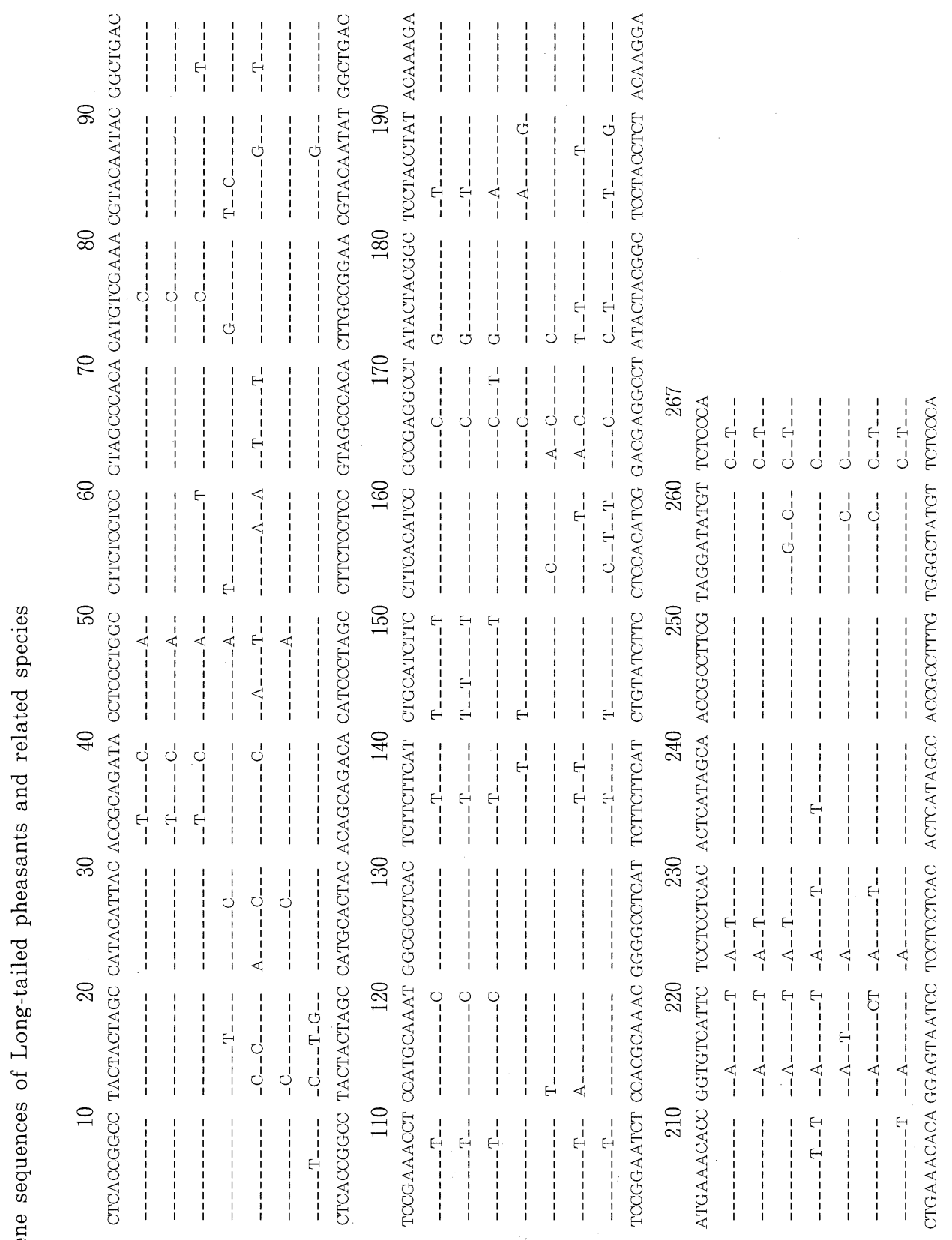

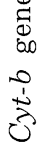

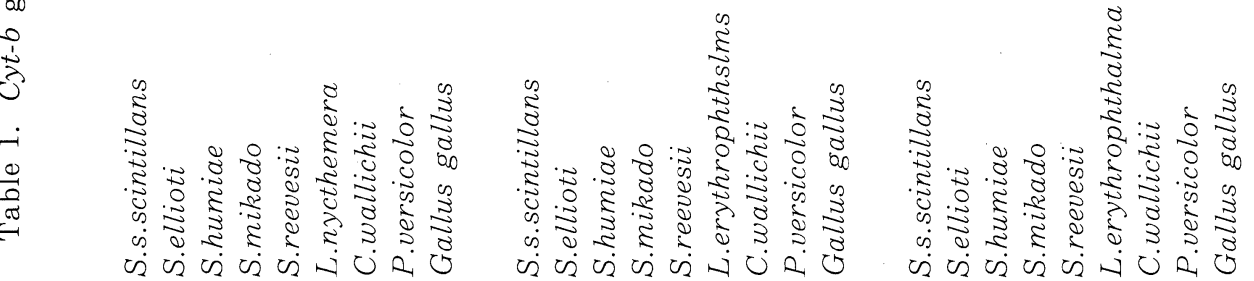


Table 2. Sequence divergence of genus Syrmaticus and some related species.

\begin{tabular}{|c|c|c|c|c|c|c|c|c|c|}
\hline \multirow[b]{2}{*}{ Species } & \multicolumn{9}{|c|}{ Sequence divergence(\%) } \\
\hline & 0 & 1 & 2 & 3 & 4 & 5 & 6 & 7 & 8 \\
\hline 0.Gallus gallus & - & 12.35 & 14.16 & 13.71 & 15.56 & 16.53 & 15.15 & 15.61 & 16.02 \\
\hline 1.Symaticus s.scintillans & $26 / 241 *$ & - & 7.46 & 7.87 & 9.13 & 9.99 & 7.95 & 9.20 & 10.44 \\
\hline 2.Symaticus ellioti & $34 / 233$ & $9 / 248$ & -- & 0.38 & 2.67 & 9.92 & 8.71 & 7.48 & 7.87 \\
\hline 3.Symaticus humiae & $33 / 234$ & $20 / 247$ & $1 / 266$ & -- & 3.05 & 10.34 & 9.13 & 7.89 & 8.28 \\
\hline 4.Symaticus mikado & $37 / 230$ & $22 / 245$ & $7 / 260$ & $8 / 259$ & --- & 12.00 & 9.57 & 8.32 & 10.81 \\
\hline 5.Symaticus reevesii & $40 / 227$ & $21 / 246$ & $22 / 245$ & $25 / 242$ & $29 / 238$ & $-\cdots$ & 11.72 & 10.44 & 11.27 \\
\hline 6. Lophura eryhrophthalma & $36 / 231$ & $18 / 249$ & $24 / 243$ & $25 / 242$ & $26 / 241$ & $27 / 240$ & --- & 6.63 & 9.47 \\
\hline 7.Catreus wallichii & $38 / 229$ & $21 / 246$ & $20 / 247$ & $21 / 246$ & $22 / 245$ & $24 / 243$ & $22 / 245$ & --- & 7.83 \\
\hline 8.Phasianus versicolor & $37 / 230$ & $22 / 245$ & $19 / 248$ & $21 / 246$ & $28 / 239$ & $25 / 242$ & $26 / 241$ & $24 / 243$ & --- \\
\hline
\end{tabular}

* Number of base pairs(different/common).

to 1.96 Myr. using evolution speed of 2-4\%/Myr. of Wilson et al. (1985).

In comparisons to species in other genera, the Cheer Pheasant at $7.83 \%$ had the closest relationships among the Green Pheasants. In addition, among the Copper Pheasants, the Crestless Fireback Pheasant of genus Lophura was $9.20 \%$ and the Green Pheasant of the genus Phasianus was $10.44 \%$.

\section{DISCUSSION}

When we examined the genera Catreus, Phasianus and Lophura, which are considered to be closely allied to genus Syrmaticus, they were divided between the cluster containing the genus Phasianus and the various clusters containing the genera classified as the genus Syrmaticus. The Copper Pheasant included in the genus Syrmaticus and the four other Long-tailed Pheasant species were recognized to have a disparity of $7.46-10.44 \%$.

There are two theories regarding the origin of the genus Phasianus, namely, the Common Pheasant type either from the west or from southern China. Of these, Kuroda \& Ito (1987) consider the latter to be the most promising and point out the need to survey the Common Pheasant (Phasianus colchicus) group. Based on the theory of the origin from southern China, a close relationship to the genus Syrmaticus would not be strange since it is considered to have originated in the same region.

Delacour (1977) and Morioka (1988) claim that the genus Phasianus and Syrmaticus should be separated due to differences in form. At the present stage, the difference between (3) cluster, including the Elliot, Hume and Mikado Pheasant, and the Green Pheasant is recognized to be $10.81 \%$.

Johnsgard (1986) and Kuroda \& Ito (1987) position it as a sub-genus group; however, it is obvious that it is moving toward separation and, therefore, there would probably be no problem in isolating this as a separate genus. If we must have 2 separate genera, then we should use the genus name Syrmaticus because 
Syrmaticus is positioned at the root of this tree.

The Cheer Pheasant is unique in being considered the sole species of the genus and there are various theories regarding its classification. Comparisons of Cyt-b gene arrays indicate that it is included in the same cluster as the genus Phasianus, which coincides with the results of research by Morioka (1988), who claims that it is closely related to the genus Phasianus. Although it is currently positioned before the genus Syrmaticus, it would probably be reasonable to place it between the two genera Syrmaticus and Phasianus.

\section{LITERATURE CITED}

Delacour, J., 1977. The Pheasant of the World (2nd ed.), Spur Publications, Hindhead and World Pheasant Association, Lamarsh.

Desjardns, P. \& Morais, R. 1990. Sequence and Gene Organization of the Chicken Mitochondrial Genome. A Novel Gene Order in Higher Vertebrates. Journal of Molecular Biology, 212: 599-634.

Irwin, M. D., Kocher, D. T. \& Wilson, C. A. 1991. Evolution of the Cytochrome-b Gene of Mammals, Journal of Molecular Evolution, 32: 128-144.

Johnsgard, P. A. 1986. The Pheasants of the World, pp.185-200, Oxford University Press, Oxford.

Knoder, C. E. 1963. Genetic analysis of hybrids between the avian genera Syrmaticus and Phasianus. Game Res. Ohio 2, 215-222.

Kuroda, H. \& ITo, K. 1987. World of Animals (Classification and rearing No.10), Dobutsu-sha, Tokyo. (In Japanese)

Morioka, H. 1988. Magnificent birds of the forest in Asia, Anima, No.195, 89-95. (In Japanese)

Peters, J. L. 1934. Checklist of Birds of the World Vol. 2, Harvard University Press, Cambridze.

The Ornithological Society of Japan 1974. Checklist of Japanese Birds (5th ed), Gakken, Tokyo.

Wilson, A. C., Cann, R. L., Car, S. M., George, M., Gyllensten, U. B., Bychowski, K. M., Higuchi, R. G., Palumbi, S. R., Prager, E. M. \& Stoneking, M. 1985. Mitochondrial DNA and two perspectives of evolutionary genetics. Journal of the Linnean Society 26: 375-400.

(Received 14 March 1998; Accepted 8 February 1999) 
和文抄録 Japanese Summary of Papers in English

\section{ヤマドリ属の分類学的関係}

(Relationships of Syrmaticus and Phasianus by

Cyt-b Gene Array Comparison. 47: 133-138)

\section{宗近 功 $^{1} \cdot$ 野沢康平 $^{2} \cdot$ 鈴木 仁 $^{3}$}

1 千葉市動物公園 T264-0037 千葉市若葉区源町 280 番地

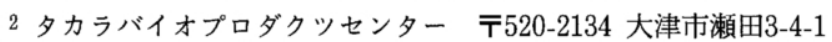

3 北海道大学大学院地球環境科学研究科生態遺伝学講座 $\mathbf{T} 060-0810$ 札幌市北区北 10 条 西 5 丁目

ヤマドリ属とキジ属の分類は定かではなく，1つの属とする説と分離独立させるとする 2 つの説が あり，いまだ論争が続いている. ヤマドリ属 (genus Syrmaticus) の分類学的位置づけを確定する ため, キジ属 (genus Phasianus) および両属に近いとされるコシアカキジ属 (genus Lophura), カンムリキジ属 (genus Catreus) の類縁関係について Cyt-b 遺伝子配列の比較から検討をおこなっ た.

1)ヤマドリと 2)オナガキジと 3 )カラヤマドリ・ビルマカラヤマドリ・ミカドキジと4)ウチワキ ジ・エボシキジ・ニホンキジがそれぞれクラスターを形成した. 分類学的位置づけが論議されている エボシキジ (Cheer Pheasant) はニホンキジ（Green Pheasant）のクラスターに含まれ，ヤマド リ属 (genus Syrmaticus) よりもむしろキジ属 (genus Phasianus) に近かった. 